\title{
Memahami Identitas : Studi Kasus Identitas Agama Orang Baduy di Kabupaten Lebak (Analisis Politik Praktis Terhadap Identitas Suku Baduy)
}

\section{Peri Irawan $^{1}$}

Ilmu Pemerintahan, Universitas Sultan Ageng Tirtayasa 6670190043@untirta.ac.id

\section{Shidna Aisya Lessy ${ }^{2}$}

Ilmu Pemerintahan, Universitas Sultan Ageng Tirtayasa 670190043@untirta.ac.id

\author{
E-ISSN 2721-0642 \\ Article Info \\ Recieved: \\ October 122021 \\ Revised: \\ November 272021 \\ Accepted: \\ December 162021 \\ Doi Number \\ https://doi.org/10.37950/ijd.v3i3.177
}

\begin{abstract}
The Baduy community's adherence to pikukuh karuhun (customary rules), especially the inner Baduy in Lebak Regency, Banten Province, uses a representation system, which is represented by Puun (customary leader). Representative democracy is based on the results of a predetermined deliberation. The Baduy do not have close ties to political parties and other public officials. The Baduy community prioritizes and attaches importance to pikukuh karuhun and tribal unity so that there are no divisions caused by political interests. The Baduy do not refuse democracy, but there are only limits with pikukuh karuhun that cannot be violated and must be preserved. This study aims to understand the reality that occurs to the Baduy community in the election process starting from voting activities, the adaptation process which is very different from the Baduy tribe, an understanding of the rights and obligations in elections and the differences in structure and reality from outside the Baduy tribe.
\end{abstract}

Keywords: subcultural society, phenomenology, political reality. 


\begin{abstract}
Abstrak
Ketaatan masyarakat Baduy terhadap pikukuh karuhun (aturan adat) terutama Baduy dalam di Kabupaten Lebak Provinsi Banten yang menggunakan sistem keterwakilan, yang diwakili oleh Puun (Pimpinan adat). Demokrasi keterwakilan tersebut berdasarkan hasil musyawarah yang telah ditentukan sebelumnya. Suku Baduy tidak memiliki kedekatan dengan partai politik dan pejabat publik lainnya. Masyarakat Baduy lebih mengedepankan dan mementingkan pikukuh karuhun dan persatuan suku agar tidak terjadi perpecahan yang diakibatkan kerana kepentingan politik. Suku Baduy tidak menolak untuk berdemokrasi, namun saja hanya terdapat batasan dengan pikukuh karuhun yang tidak boleh dilanggar dan harus tetap dilestarikan. Penelitian ini bertujuan untuk memahami realitas yang terjadi terhadap masyarakat Baduy dalam proses pemilu mulai dari kegiatan pencoblosan, proses adaptasi yang sangat berbeda dengan suku Baduy, pemahaman tentang hak dan kewajiban dalam pemilu dan perbedaan struktur dan realitas dari luar suku Baduy.
\end{abstract}

Kata kunci : masyarakat subkultural, fenomenologi, realitas politik.

\title{
Pendahuluan
}

Perlu diketahui bahwasannya Suku Baduy adalah salah satu suku yang berada di Kadujangkung, Bojong Menteng, Leuwidamar, Kabupaten Lebak, Provinsi Banten yang menjadi sorotan publik, baik secara lokal maupun nasional. Karena Suku Baduy adalah salah satu suku yang tetap mempertahankan budaya nenek moyang atau leluhurnya serta jauh dari keramaian kota yang tempat tinggalnya di alam. Identitas dari yang dianut oleh Suku Baduy yaitu Sunda Wiwitan, yang merupakan agama sinkretis antara agama Islam dengan Budha. Meskipun tempat tinggal Suku Baduy jauh dari perkotaan atau di pedalaman hutan, disamping itu Suku Baduy memiliki daya pikat atau keunikan tersendiri, diantaranya mulai dari keyakinan (kepercayaan), budaya, sosial agama dan lainnya. Dalam hal ini akan membahas tentang fokus dari agama orang Baduy sendiri.

Suku Baduy yang berada di Kabupaten Lebak, Provinsi Banten. Dimana Banten ini merupakan salah satu Provinsi yang memiliki keunikan diantaranya dari sisi budaya. Salah satu budaya yang berada di Banten ini yaitu Suku Baduy. Identitas agama suku Baduy terus dijadikan pertanyaan-pertanyaan orang-orang luar, sehingga sering sekali Suku Baduy dijadikan tempat wisata agar masyarakat mengetahui kehidupan orang Baduy yang masih kental dengan keyakinan-keyakinan nenek moyangnya dan terus menjaga kebudayaannya. Pada tahun 1977, terdapat sekitar 1.000 orang dari Suku Baduy yang melakukan perpindahan agama, yaitu dari agama Sunda Wiwitan ke agama Islam serta terdapat 120 masyarakat Baduy yang pindah ke agama Kristen. Banyak fenomena yang terjadi terhadap orang Baduy ini, diantaranya yang berkaitan dengan Agama dan kepercayaan. Dimana orang Baduy sering melakukan pindah-pindah agama mulai dari agama Kristen ke Islam, Islam ke Kristen dan Kristen.

Mayoritas Suku Baduy beragama Sunda Wiwitan, agama tersebut tidak diakui oleh negara, suku Baduy sendiri terdiri dari dua kelompok. Yaitu Suku Baduy dalam dan luar, Suku Baduy luar sudah terkombinasi dan sudah menerima hal-hal moderen, sedangkan Suku Baduy Dalam masih terus menerus mempertahankan budaya dan menolak hal-hal moderen. Dalam hal ini agama yang dianut oleh Suku Baduy tidak 
diakui oleh negara Indonesia. Dan dari aspek sosial, Suku Baduy sendiri tidak mengikuti peraturan-peraturan pemerintah, melainkan peraturan adat yang sudah melekat. Identitas agama Suku Baduy yang belum memiliki jati diri dan apa sebenarnya agama yang dianut oleh Suku Baduy tersebut yang dipimpin oleh salah satu Pu'un, karena Baduy ini adalah salah satu etnis yang terpisahkan dengan negara. Hal-hal yang bersifat administratif diantaranya yaitu identitas agama tidak diketahui.

Berbicara mengenai politik sendiri, bagaimana pada akhirnya suatu kelompok atau golongan pada hal ini adalah masyarakat baduy itu sendiri terdapat cara atau motif tersebut di samping fakta yang mengatakan bahwasannya baduy adalah warga yang masih mengacu pada adat yang tentunya sangat amat bertolak belakang artinya berbeda dengan masyarakat pada umumnya. Ketika semua kegiatan yang ada dalam masyarakat baduy ini berjalan sangat beriringan dengan adat adat yang sebelumnya telah diresmikan. Meskipun demikian, warga di baduy ini sebetulnya sangat antusias atau partisipatif walaupun secara tidak langsung dan jarang diketahui orang luar, tetapi sebetulnya justru suku Baduy ini dinamis dalam menanggapi setiap perkembangan/pertumbuhan yang terjadi di luar komunitasnya itu sendiri. Pada dasarnya memang masyarakat Baduy ini memiliki semangat dalam mengimbangi pertumbuhan berupa partisipasi dalam kegiatan berbasis kenegaraan yaitu pemilihan umum dan pemilihan kepala daerah.

Berkaitan dengan pelaksanaan kegiatan kenegaraan itu tadi tentunya sangat menarik karena dalam lingkup masyarakat baduy itu sendiri terjadi pula kondisi yang unik dimana pada pelaksanaan atau kegiatan pemilu ini seluruhnya diberikan (segala urusan) kepada puun atau jaro serta tak lupa warga adat baduy luar. Masyarakat suku Baduy dalam ini sangat menjaga kemurniannya karena mereka percaya bahwa segala sesuatu yang berhubungan duniawi apalagi tidak ada dalam penggalan leluhur mereka tidak mau mereka campuri, hal itu juga terjadi dikarenakan Masyarakat suku Baduy dalam sangat memperhatikan apa yang disebut dengan kepercayaan yang mereka pegang teguh. Kehidupan sosial budaya masyarakat suku Baduy, dipengaruhi 2 macam Lembaga yang ada hingga saat ini. Lembaga adat Baduy tidak bisa dilepaskan dengan sistem pemerintahan negara berlandaskan UU Pemerintahan di Daerah.

\section{Kerangka Teori}

\section{Identitas Agama Orang Baduy}

Dalam jurnal Hakiki (2011), disebutkan bahwa yang dirasakan saat pertama kali ke Baduy mayoritas akan memiliki pandangan tentang kelompok masyarakat yang merefleksikan keseluruhan daripada ajaran agama, yaitu menyayangi sesama makhluk dan sang Pencipta. Akan tetapi seringkali masyarakat yang ada dalam kategori luar Baduy memberi sebutan pada suku Baduy ini sebagai masyarakat yang menganut agama sunda wiwitan.

Masih dalam jurnal yang sama, dijelaskan penamaan agama Sunda Wiwitan artinya sunda mula-mula. Ini perlu diketahui merupakan suatu penyebutan yang mengarah tak lain untuk identitas agama orang Baduy ini yang dimana menggambarkan bagaimana kepercayaan tersebut adalah yang paling awal dari masyarakat sunda. Jika ditelisik dari sejarahnya, penamaan agama suku Baduy berawal pada ritual sembahyang yang mereka lakukan dilambangkan dengan Arca Domas sebagai leluhur. Disebutkan juga bahwa dasar kepercayaan yang terdapat pada masyarakat Baduy sama dengan ajaran agama Sunda wiwitan ini adalah suatu bentuk dari kepercayaan yang memiliki 
sifat monoteis, roh nenek moyang yang senantiasa diberi penghormatan dan juga tak lupa bahwa terdapat kepercayaan yang ditujukan pada satu kekuasaan yang lebih dikenal dengan sebutan Sanghyang Keresa yang berarti Yang Maha Esa.

Baduy yang berasal dari hirarki tua menjadi apa yang kemudian diyakini oleh Masyarakat Baduy itu sendiri. Kepercayaan ini membuat mereka seakan bertanggung jawab atas keberlangsungan hidup manusia dimuka bumi dan keutuhan alamnya. Mereka sering melakukan tapa yang bertujuan agar kehadiran bumi ini selalu berada dalam lindungan atau dalam artian baik baik saja. Dari semua keyakinan tersebut, mereka menamainya sebagai Agama Slam Sunda Wiwitan. Nama sebutan tersebut dipercayai oleh mereka sebagai agama khusus yang dimana ditujukkan kepada khalayak Baduy serta dengan tegas tidak dapat disebarkan kepada kelompok masyarakat yang berada dalam kategori luar Baduy.

Tidak seperti umat beragama pada umunya, artinya bahwa Masyarakat Baduy sebagai kelompok penganut agama Sunda wiwitan ini tidak memiliki suatu pedoman yang dipahami sebagai kitab suci karena perlu diketahui bahwa mereka meyakini jika ajarannya bersatu dalam interaksi umat dengan alam. Maka dari itu agama Slam Sunda Wiwitan hanya dikhususkan untuk masyarakat Baduy saja. Dalam jurnal Wahid (2011), disebutkan menurut James Frazer bahwa agama Sunda Wiwitan menyatakan manfaat simbolik yang terdapat pada hubungan yang terjalin antara sosial budaya dan kosmologi alam Baduy. Keimanan masyarakat Baduy kepada Allah SWT cuma bisa dirasakan pada kalimat syahadat, namun disamping itu tetap berpedoman pada pikukuh atau suatu ketentuan adat sifatnya mutlak yang diwahyukan oleh para pendahulu yang menjadi leluhurnya dengan tujuan tak lain agar selalu pegang teguh dan dijadikan pedoman dalam menjalankan keseharian di masyarakat Baduy tersebut.

Kami menyimpulkan dalam penjelasan diatas secara sederhananya, kepercayaan suku Baduy ini cukup dekat dengan agama Islam. terlebih dari pelafalan kata "slam" hampir mirip dengan kata "islam". Selain itu, jika kita mengacu pada keyakinan yang dimiliki orang Baduy juga yang hanya percaya satu Tuhan yang disebut mereka yakni Gusti nu Maha Agung atau Sanghyang Tunggal. Agama Sunda wiwitan yang dimaksud ini bisa dirasakan melalui praktik realisasinya merupakan agama sinkretisme atau percampuran antara Islam dan Hindu. Masyarakat Baduy ini mempercayai bahwa mereka menganggap sangat serius suatu pemujaan yang diberikan kepada nenek moyang atau para karuhun yang dipercaya memberikan kekuatan lahir dan batin kepada keturunannya. Kesakralan dalam nilai ajaran yang dianut oleh suku Baduy ini yang pada akhirnya mengakibatkan mereka patuh dan sangat hati hati dalam melakukan berbagai ketaatan pada buyut, pikukuh adat, dan juga pantangan. Keimanan yang seperti itu membuat semangat mereka dalam membentengi keutuhan alam dan hidup beriringan satu dengan yang lainnya.

\section{Hak Politik Masyarakat Baduy}

Dalam tulisan Desiana, A (2021) menuliskan Hak politik warga negara khususnya dalam menggunakan hak pilih pada setiap pemilihan adalah hak absolut. Penyaluran Hak politik dilaksanakan melalui Pilkada dan menjadi salah satu tolak ukur keberhasilan dalam demokrasi. Pelaksanaan Pilkada yang dijalankan oleh masyarakat Baduy yakni menyerahkan segala urusan kehidupan kepada Puun serta masyarakat Baduy Luar. Dalam hal ini, masyarakat suku Baduy Dalam tidak ingin kemurniannya luruh terhadap sesuatu yang tidak ada dalam penanggalan leluhurnya. Maka dari itu setiap Pemilihan 
baik pada Pilpres sampai Pilkada masyarakat Baduy Dalam tetap berpegang teguh pada kepercayaan yang dianut. Selanjutnya, pada Praktik pemerintahan di masyarakat Baduy, Puun dianggap sebagai pimpinan paling tinggi untuk segala urusan kehidupan dan memiliki hubungan dengan Karuhun (Hikmawan, 2014). Pada Pilkada, memilih merupakan salah satu bagian dari Hak Politik warga negara. Namun, masyarakat Baduy tidak memilih secara langsung tetapi dengan sistem keterwakilan.

Masih dengan tulisan yang sama, dituliskan Pemenuhan Hak masyarakat Baduy menjadi hal penting bagi pemerintah untuk mendata masyarakat yang terletak di pedalaman kampung, karena banyak dari mereka yang belum terdaftar di catatan sipil. Seperti yang kita ketahui, Hak memilih dan dipilih adalah salah satu hak sipil dan politik dalam berwarganegara. Namun belum terimplementasikan di masyarakat Baduy sebab terbentur adat dan peraturan yang ada. Maka dari itu, masyarakat Baduy kerap kali enggan mendaftarkan diri untuk kepentingan politik tersebut.

Dalam tulisan ini disebutkan yang dikutip dari jurnal milik Moh, Ali.B. (2019), terdapat banyak yang menempatkan partisipasi politik masyarakat suku Baduy dari perspektif budaya (Riswanda et al., 2020). Dari hal tersebut struktur adat mempengaruhi bagaimana masyarakat berpolitik serta menentukan pilihan terhadap partai atau calon kandidat tertentu. Keberadaan Lembaga adat yang dipimpin oleh Puun dan Jaro Pamarentah sangat strategis dalam mengatur masyarakat adat agar tetap menjalankan pikukuh adat, termasuk juga pemilu dilaksanakan.

\section{Metode Penelitian}

Metode yang digunakan yaitu penelitian kualitatif deskriptif dengan menggunakan pendekatan studi kasus. Didalamnya menjelaskan tentang fokus satu kasus yaitu "Identitas Agama Suku Baduy di Kabupaten Lebak" yang diamati dan dianalisis atas pengalaman peneliti dan sumber informasi - informasi lainnya seperti jurnal - jurnal. Kasus yang diamati yaitu kasus secara kelompok, sehingga penelitian dilakukan secara intensif yang memusatkan terhadap satu objek yang dijadikan sebagai satu kasus. Dalam metode studi kasus, subjek dari penelitian bisa dilakukan dalam kategori individu, institusi, masyarakat maupun kelompok. Sumber-sumber data dikumpulkan dari berbagai sumber dan berlaku terhadap kasus yang sedang diangkat.

Studi kasus merupakan pengujian secara rinci terhadap satu orang subjek atau orang terhadap peristiwa - peristiwa tertentu (Bogdan dan Bikien, 1982). Dalam hal ini peneliti lebih memfokuskan terhadap satu subjek terhadap kasus "Identitas Agama Baduy di Kabupaten Lebak." Agar penelitian bisa terpusatkan dan fokus terhadap satu kasus, dalam konteks ini yaitu secara berkelompok bukan menganalisis secara individu (Mahpudin, 2019). Fenomena dalam penelitian ini yaitu menganalisis Identitas dari agama Suku Baduy yang tidak teridentitas secara administratif, karena Suku Baduy sendiri tidak mengikuti peraturan - peraturan pemerintah. Agama - agama yang dianut oleh orang - orang Baduy diantaranya seperti Islam, Sunda Wiwitan dan Kristen.

Terdapat beberapa batasan dalam melakukan penelitian kualitatif dengan pendekatan studi kasus diantaranya yaitu :

1. Sasaran penelitiannya adalah manusia, latar, dokumen dan peristiwa.

2. Peneliti meneliti sasaran - sasaran tersebut secara dalam, untuk memahami terhadap konteks dari berbagai kaitan-kaitannya.

3. Sumber-sumber data yang diperoleh bisa dihasilkan dari wawancara, observasi secara langsung, audio - visual, wawancara, dokumentasi atau laporan-laporan. 


\section{Hasil dan Diskusi}

\section{Realitas Subjektif Suku Baduy}

Suku Baduy tidak menekankan atas keharusan dalam mengenyam pendidikan, baik itu pendidikan formal maupun informal. Bagi mereka kemampuan terhadap membaca, menulis, dan menghitung dirasa sangat cukup untuk menjalankan aktivitas kehidupan sosial. Suku Baduy sangat mengedepankan kejujuran dalam menjalankan kehidupan sehari-hari, disamping itu masyarakat Baduy sangat menjunjung tinggi terhadap kepatuhan amanat leluhur atau nenek moyang dalam menjalankan aktivitasnya. Praktik tersebut bisa dilihat dalam menyelesaikan masalah, dimana masyarakat Baduy lebih mengedepankan mufakat atau musyawarah. Sedangkan dalam berpolitik ataupun hak pemilihan, masyarakat Baduy menggunakan sistem keterwakilan, karena jika masyarakat Baduy berpolitik dan memiliki perbedaan pilihan, maka akan terjadi pertengkaran sesama suku Baduy dan hal tersebut sangat dihindari.

Dalam Pemilihan Umum (Pemilu), masyarakat Baduy memiliki hak dalam memilih pemimpin, baik itu eksekutif maupun legislatif. Hal tersebut dijelaskan dalam Pasal 1 Ayat (2) Undang-Undang 1945 tentang perlindungan hak pilih bagi warga negara Indonesia. Akan tetapi dalam Pemilihan Umum (Pemilu) tersebut, masyarakat Baduy menyerahkan kepada Puun (ketua suku di Baduy). Sehingga Puun akan memilihkan berdasarkan amanat masyarakatnya serta memilih pemimpin yang akan memberikan kemanfaatan dan perubahan dimasa yang akan datang. Dalam pergolakan politik di Indonesia, masyarakat Baduy tidak ikut serta menjadi aktivis partai, mencalonkan dirinya sebagai anggota legislatif, atau petugas lainnya dalam hal kepanitiaan dalam pemilihan. Masyarakat Baduy tetap taat dan patuh kepada peraturan pemerintah dan tetap menjadi masyarakat Baduy biasanya. Hal ini bisa dilihat dari partisipasi masyarakat Baduy saat pemilihan Bupati Lebak tahun 2018 yang mencapai 38 \% dari jumlah Data Pemilih Tetap (DPT) sebanyak 6. 810 jiwa (Antusiasme Suku Baduy Ikut Pilkada Lebak 2018 - Pilkada Liputan6.com).

Pada saat Pemilihan Umum (Pemilu) masyarakat Baduy memiliki karakteristik yang berbeda-beda, dimana terdapat dua karakteristik. Pertama terdapat masyarakat Baduy yang tetap pergi ke sawah, ladang atau huma (kebun), dan kedua ada yang tetap datang ke TPS untuk menyaksikan Pemilihan bahkan penghitungan suara. Masyarakat Baduy sangat antusias dalam menyambut pesta demokrasi baik Baduy dalam maupun luar. Akan tetapi ajaran leluhur yang menjadikan masyarakat Baduy tidak bisa memilih dan hanya bisa keterwakilan oleh Puun itu sudah cukup. Menurut Jaro Saija, pada pemilu saat ini para masyarakat terbagi menjadi dua bagian, ada yang tetap pergi ke ladang dan ada juga yang menyempatkan datang ke lokasi TPS, tapi itu hanya berlaku untuk Baduy luar. Baduy dalam belum bisa melaksanakan baik Pemilu maupun pilkada tersebut, ada tiga desa yang masih benar-benar belum bisa mengikuti pesta demokrasi tersebut, berbeda dengan hal-nya jika Baduy dalam menyatakan diri pindah ke Baduy luar baru bisa mengikuti pesta demokrasi (Desiana, 2021).

\section{Institusional dan Legitimasi}

Hak memilih dan dipilih merupakan salah satu hak sipil dan politik dalam berwarga negara yang belum terimplementasikan di Masyarakat Baduy, karena terbenturnya adat serta peraturan yang ada, maka dari itu masyarakat Baduy dalam enggan untuk mendaftarkan diri untuk kepentingan politik tersebut (Ramadhan, 2018). Selain itu juga sarana untuk melakukan pencatatan kependudukan sangat sulit, melihat 
medan yang sangat terjal untuk sampai ke pedalaman Masyarakat Baduy. Masyarakat adat Baduy mempunyai hak politik yang sama, seperti dijelaskan dalam pasal 56 ayat (1) Undang-Undang republik Indonesia Nomor 10 Tahun 2016 yang mana dimaksud dalam pasal tersebut adalah setiap warga negara yang sudah berumur 17 tahun atau sudah menikah mempunyai hak politik yang sama di mata negara (Desiana, 2021).

Masyarakat Baduy memiliki hak politik karena merupakan hak bagi setiap warga negara, masyarakat Baduy tidak anti demokrasi, akan tetapi lebih mengedepankan dan menjaga pertauran nenek moyang atau leluhurnya. Sehingga partisipasi politik masyarakat Baduy terutama Baduy dalam dilakukan secara keterwakilan oleh Puun berdasarkan hasil mufakat dan tetap tunduk terhadap peraturan pemerintah selama tidak merusak hukum adat yang berlaku (Hikmawan, 2017).

Legitimasi terhadap masyarakat Baduy yaitu tetap menjaga dan mentaati pikukuh atau nilai leluhur atau pikukuh karuhun. Sama halnya dengan suatu lembaga yang melegitimasi adanya sosialisasi politik yang dilakukan oleh pemerintah, media massa dan partai politik kepada seluruh masyarakat Indonesia, salah satunya adalah masyarakat Baduy. Dalam pemilihan umum, panggiwa dan jaro adalah penghubung untuk masyarakat adat untuk mensosialisasikan pemilu. Kepala Desa memiliki kewajiban untuk mensosialisasikan pemilu yang merupakan tugas dari pemerintah kepada masyarakat Baduy, sehingga adanya legitimasi melalui Undang-Undang 1945. Sedangkan masyarakat Baduy memiliki legitimasi dalam aturan adat.

Tidak adanya paksaan bagi masyarakat Baduy dalam menggunakan hak pilihnya; tidak adanya sanksi bagi seseorang yang tidak menggunakan hak suaranya; masyarakat baduy tidak memiliki keberpihakan kepada kandidat, caleg, parpol dan lainnya; larangan masyarakat baduy dalam terhadap penempatan TPS, penempatan TPS hanya boleh dilakukan di Baduy luar sehingga jika warga Baduy Dalam yang ingin mencoblos maka tinggal menuju ke TPS yang terdekat di Baduy Luar; tidak adanya kampanye politik yang dilakukan oleh peserta politik di Baduy dalam karena dapat memicu perpecahan; $\mathrm{Pu}^{\prime}$ un tidak membolehkan masyarakat Baduy dalam mengikuti Pemilu. Pu'un dipercaya oleh warga Baduy memiliki ilmu kebatinan, wangsit, ataupun kharisma yang dapat dipergunakan untuk memberikan keputusan, wejangan, dan ramalan kepada warga. Beragam konstruksi yang dikeluarkan oleh Pu' un wajib ditaati karena ia memiliki kekuasaan untuk melegitimasi pada masyarakat Baduy (Karman, 2014).

\section{Penyesuaian Realitas Terhadap Politik Praktis Suku Baduy}

Masyarakat Baduy memiliki kewenangan yang sama dengan masyarakat lainnya dalam hal memilih dan dipilih, karena hal tersebut merupakan salah satu dari hak sipil dan politik dalam berwarganegara. Hak kebebasan masyarakat Baduy dalam hak memilih dan dipilih ditentukan dalam Undang-Undang Dasar 1945 dalam pasal 56 ayat (1) Nomor 10 Tahun 2016 yang memiliki kandungan yaitu setiap warga negara yang sudah menginjak umur 17 dan seterusnya memiliki hak politik di mata negara. Akan tetapi dalam realitanya, masyarakat Baduy belum mengimplementasikan karena ada beberapa faktor, diantaranya yaitu terbenturnya dengan peraturan adat yang lebih penting.

Faktor adat yang mengakibatkan masyarakat baduy tidak mendaftarkan diri untuk kepentingan politik, namun dengan adanya keterbenturan, masyarakat Baduy bukan tidak peduli dengan demokrasi, melainkan menggunakan sistem keterwakilan yang diwakilkan oleh kepala suku Baduy (Puun) berdasarkan hasil keputusan 
musyawarah terlebih dahulu untuk menentukan kandidat atau calon yang akan dipilih, disamping itu pencatatan kependudukan masyarakat Baduy terutama Baduy dalam sangat sulit dilakukan karena sangat sulit diakses atau medan terjal yang sulit untuk sampai ke lokasi Baduy dalam.

Sampai saat ini belum adanya kepastian hukum untuk melindungi eksistensi mereka agar tidak terancam oleh kepentingan ekonomi, sosial, politik dan kepentingan lainnya (Desiana, 2021). Dengan itu harus adanya pengayoman dari masyarakat terhadap hak-hak warga negara serta adanya kesamaan di depan politik dan hukum agar tidak terjadi pemanfaatan terhadap suku Baduy dalam berpolitik maupun lainnya, karena bagi suku Baduy dengan adanya keterwakilan dalam memilih itu sudah terwakilkan, namun dalam hal ini yaitu adanya pemanfaatan terhadap eksistensi suku Baduy dalam kontestasi ataupun Pemilihan Umum (Pemilu). Namun dalam kontestasi dalam pemilihan umum di Baduy tidak besar, berbeda dengan masyarakat luar lainnya. Karena kontraksi dari masyarakat Baduy yaitu menjaga pikukuh leluhur bukan untuk mengurus negara, dan jika adanya pelanggaran yang akan dilakukan maka akan terjadi sebuah kejadian bahaya yang akan menimpa suku Baduy.

Dalam sejarah suku Baduy, wiwitan tidak memiliki keberpihakan kepada pasangan calon, partai politik ataupun aktor negara lainnya. Karena jika ada keberpihakan, maka akan mengakibatkan goncangan yang sangat besar yang akan menimpa suku baduy, adanya ketidakharmonisan antara masyarakat Baduy, serta perpecahan persatuan antara masyarakat Baduy untuk menjalankan amanat pikukuh atau amanat leluhur (Kurnia et al., 2010). Di Dalam pikukuh leluhur terdapat panduanpanduan dalam menegakan aturan serta bagaimana kekuasaan digunakan dalam interaksi antara masyarakat Baduy.

\section{Kesimpulan}

Dari pemaparan yang telah diuraikan diatas dapat kita simpulkan bahwa dalam Pemilihan Umum (Pemilu), masyarakat Baduy memiliki hak dalam memilih pemimpin, baik itu eksekutif maupun legislatif. Akan tetapi dalam Pemilihan Umum (Pemilu) tersebut, masyarakat Baduy menyerahkan kepada Puun (ketua suku di Baduy). Masyarakat adat Baduy mempunyai hak politik yang sama seperti yang tercantum dalam Undang-Undang republik Indonesia Nomor 10 Tahun 2016 pasal 56 ayat (1). Masyarakat Baduy tidak anti demokrasi, akan tetapi lebih mengedepankan dan menjaga pertauran nenek moyang atau leluhurnya. Sehingga partisipasi politik masyarakat Baduy terutama Baduy dalam dilakukan secara keterwakilan oleh Puun. Sampai saat ini belum adanya kepastian hukum untuk melindungi eksistensi mereka agar tidak terancam oleh kepentingan ekonomi, sosial, politik dan lainnya.

\section{Tentang Penulis}

Penulis merupakan peneliti dari Ilmu Pemerintahan, Universitas Sultan Ageng Tirtayasa, Provinsi Banten, Indonesia.

\section{Ucapan Terima Kasih}

Kami ucapkan terima kasih kepada Tuhan yang maha Esa, dosen pengampu dan seluruh pihak yang terlibat dalam penyusunan jurnal ilmiah ini. 


\section{Referensi}

Antusiasme Suku Baduy Ikut Pilkada Lebak 2018 - Pilkada Liputan6.com_diakses tanggal 27 November 2021 pukul 18.41 WIB.

Desiana, A. (2021). Pemenuhan Hak Politik Warga Masyarakat Adat Baduy. 1-74.

Edwar, A. (2021). Keagamaan Suku Baduy Lebak Banten : Antara Islam dan Islam Sunda Wiwitan. Journal of Islamic Education, 3 (1), 39-54.

Hakiki, K. M. (2011). Identitas Agama Orang Baduy. Al-Adyan: Jurnal Studi Lintas Agama, 6(1), 61-84.

Hikmawan, M. D. (2014). Politik Perbedaan : Demokrasi dalam Paradoks. Universitas Gdjah Mada.

Hikmawan, M. D. (2017). Pluralisme Demokrasi Politik di Indonesia. Journal of Governance, 2(2), 223-247. https:// doi.org/http://dx.doi.org/10.31506/jog.v2i2.2678

Karman. (2014). Dialektika Masyarakat Baduy Dalam Memaknai Realitas Pemilihan Umum 2014 Dialectic of Baduy Community in Meaning Reality of General Election 2014. 17 No.2, D, 89-102.

Kurnia, A., Sihabudin, A., \& Yustianti, F. (2010). Saatnya Baduy bicara: lojor teu meunang dipotong, pondok teu meunang disambung, gunung teu meunang dilebur, lebak teu meunang dirusak, buyut teu meunang dirobah. Bumi Aksara.

Mahpudin. (2019). Demokrasi dan Kebangkitan Politik Identitas: Refleksi Perjalanan Demokrasi Indonesia Pasca Orde Baru. International Journal of Demos, 1(1), 1-18.

Ramadhan, G. (2018). Identitas Dan Gerakan Sosial Di Rumpin. Polinter, 3(2), 1-11.

Riswanda, Hikmawan, M. D., Ramadhan, G., \& Nurrohman, B. (2020). Making Sense of The Politics of Recognition: Indicators of Religious Tolerance in Banten, Indonesia. 13(11), 3386-3397. 